UDC 332.145

DOI: $10.20535 /$ SRIT.2308-8893.2021.2.04

\title{
DEVELOPING AN ALGORITHM FOR RAPID ASSESSMENT OF LIVING STANDARDS AND QUALITY OF LIFE OF THE POPULATION IN THE REGION
}

\author{
M.A. LESNICHAYA, O.A. KOLCHINA, E.V. PAHOMOV
}

\begin{abstract}
The article presents the rapid assessment methodology that allows analysts to carry out qualitative monitoring of the living standards of the population using a wide range of methods for statistics processing (factor analysis, cluster analysis, discriminant analysis, method of combining indicators of different dimensions). This methodology is characterized by the high speed of mathematical calculations, availability to users with different skill levels and universal applicability to various study objects. The rapid assessment method is intended for screening the living standards of the population and activity quality of the territorial authorities, taking into account a different set of indicators. This article offers the author's indicator system for assessing the living standards and quality of life of the population. The methodology algorithm describes flowcharts of the index method for combining statistical observations of different dimensions, which make it possible to automate the process of territory ranking. The study covers 12 urban districts and 43 municipal districts of Rostov Oblast. The methodology described in the article will help eliminate a subjective factor while monitoring, rationally distribute financial resources allocated annually by the authorities to support programs for socio-economic development of the territory, increase the economic efficiency and implementation speed of innovative projects that have a direct impact on the living standards and quality of life of the population.
\end{abstract}

Keywords: living standards, variable reduction, clustering, discriminant analysis, ranking.

\section{INTRODUCTION}

According to the Strategy of Spatial Development of the Russian Federation for the period up to 2025 (approved by the Order of the Government of the Russian Federation dated February 13, 2019 No. 207-p), the priority development trend is to ensure the sustainable and balanced spatial development of the Russian Federation aimed at reducing interregional differences in the living standards and quality of life of the population, accelerating economic growth and technological development, and ensuring the national security of the country. In order to achieve this goal, the authorities need to direct their management measures at the solution of long-standing and most urgent problems connected with social inequality and high levels of poverty. A real decrease in these indicators is the main criterion for socio-economic progress of the Russian Federation and its subjects.

In this regard, it becomes necessary to develop and implement a scientifically grounded concept of improving the living standards and quality of life. This concept, first of all, should be based on an effective system of mathematical assessment methods, allowing to form an information and analytical platform for supporting the management decisions based on various data sources. This article tries to achieve the objective by developing a universal algorithm for rapid 
assessment intended to screen the living standards of the population and quality of the territorial authorities' activities, taking into account a different set of indicators and system analysis methods. 12 urban districts and 43 municipal districts of Rostov Oblast were selected as a study object, because Rostov Oblast has implemented a successful practice of "Building a regional poverty profile" aimed at identifying poor citizens (the practice was supported by Lipetsk Oblast, the Republic of Sakha, Novgorod Oblast) [https://smarteka.com/practices/ vyavleniemaloimusih-grazdan-s-maksimal-nojdekompoziciej-harakteristik-maloimusih.].

The proposed rapid assessment method will enhance this service prospects accumulating the data not only by category of poor citizens, but also on a number of key indicators (investments, level of consumption possibilities, level of digitalization, number of middle class representatives, etc.) influencing on increasing the living standards and quality of life of the population.

\section{BLOCK DIAGRAM OF RAPID ASSESSMENT OF THE LIVING STANDARDS AND QUALITY OF LIFE OF THE POPULATION}

Modern methods for assessing the living standards of the population refer to the complex systems which are difficult to be formalized. They are mainly based on an expert approach, inaccurate description and measurement errors. These all significantly distort the study results. The developed method for rapid assessment has a number of advantages, because it accumulates various system analysis methods complementing each other and allowing to avoid the data assessment subjectivity. In the context of global digitalization this method provides a decision-maker with an objective information base for the implementation of strategic decisions in a short period of time.

\section{FORMATION OF INDICATOR SYSTEM}

The first stage of rapid assessment deals with development of an indicator system based on collection, systematization, analysis of quantitative and qualitative information at the level of empirical indicators. The indicator system should be as complete as possible, taking into account all input and output elements to avoid distortion in the relationships between the model parameters. As data processing is carried out in the information system with a complex of system analysis methods, the number of data can be maximum, because the obtained results will be interpreted in an easier way and errors will be minimal. Due to the fact that many factors influence on the living standards and quality of life of the population, and depending on a time lag, some of them may have a random nature, it is more appropriate to consider this impact through stochastic processes, which will reveal a trend in the assessment indicators.

When forming an author's indicator system of the living standards and quality of life in the municipalities of Rostov Oblast, the work of N.V. Zubarevich (Faculty of Geography, Moscow State University) "Assessment of the quality of life index" was used, the analysis of the methodology of the British research center The Economist Intelligence Unit (analysis division of The Economist), The Legatum Prosperity Index (LPI) and the City Development Index (CDI) [N.V. Zubarevich 2019] were also taken into account. The analyzed methods and indices have their indisputable advantages. However, they have a major disadvantage, 
namely, they have no indicators reflecting the development and implementation level of digital technologies, which have a significant impact on the living standards and quality of life of the population (Fig. 1). During the pandemic, these are digital technologies that made it possible for people to continue working, communicate with their loved ones and provide themselves with essential goods. The digital technologies allowed people who have temporarily lost their jobs to learn the skills of remote work and new professions, allowed small businesses to increase their profits by using online platforms with an unlimited number of consumers, etc. The proposed indicator system meets modern realities and new challenges. The author's indicator system is presented in Table 1.

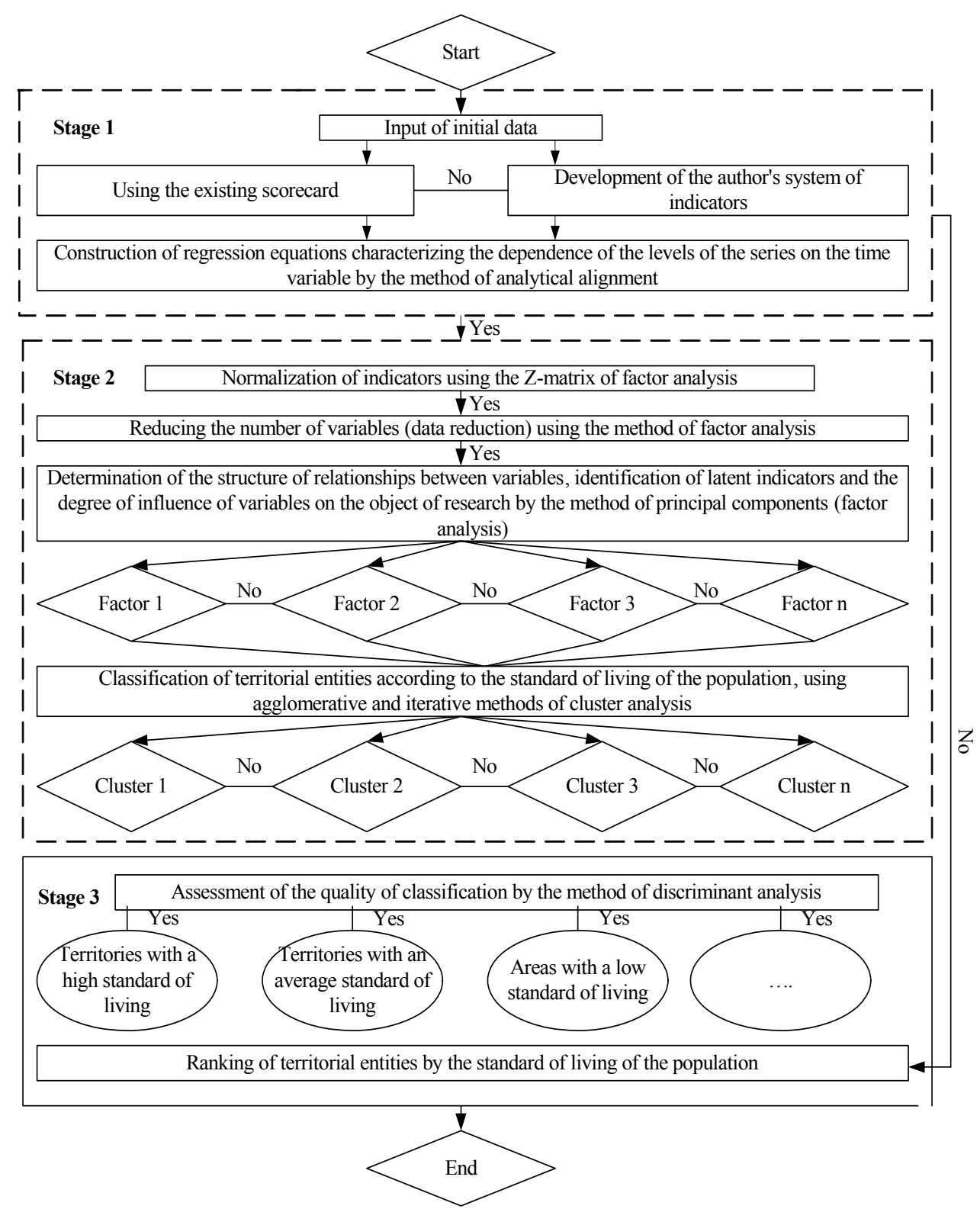

Fig. 1. Algorithm for the author's assessment of the living standards and quality of life of the population 
Table 1. The author's indicator system for assessing the living standards and quality of life of the population

\begin{tabular}{|c|c|}
\hline Income of the population & Human potential \\
\hline $\begin{array}{l}\text { Average monthly salary of one employee. } \\
\text { Unequal degree in distribution of income } \\
\text { of the population. } \\
\text { Poverty level of the population. } \\
\text { Consumption possibilities of the population. } \\
\text { Savings rate }\end{array}$ & $\begin{array}{l}\text { Number of the young adults. } \\
\text { Education level. } \\
\text { Life expectancy. } \\
\text { Air pollutant emissions }\end{array}$ \\
\hline Socio-economic indicators in the territory & Digitalization \\
\hline $\begin{array}{l}\text { Migration inflow }(+) \text {, migration outflow }(-) \text {. } \\
\text { Local budget surplus }(+) \text {, local budget } \\
\text { deficit }(-) \text {. } \\
\text { Crime rate. } \\
\text { Level of registered unemployment. } \\
\text { Investment amount }\end{array}$ & $\begin{array}{l}\text { Number of legal and other persons, who } \\
\text { have a key of an enhanced qualified } \\
\text { electronic signature. } \\
\text { Rendering of public and municipal } \\
\text { services through Multifunctional Public } \\
\text { Services Centers (MPSCs). } \\
\text { Proportion of the population using the } \\
\text { Internet }\end{array}$ \\
\hline
\end{tabular}

For a deeper analysis of statistical data, the rapid assessment methods accumulate indicators over several years to build up time series using the analytic method of fitting constants, as the change in levels of time series is expressed by certain mathematical functions and the rules are set in such a way that the series value is predicted quite accurately. This improves the quality of the study results.

\section{GROUPING OF VARIABLES AND CLASSIFICATION OF THE STUDY OBJECTS}

Grouping the diverse data into homogeneous populations classified according to the certain rules, taking into account their characteristic features. The first stage of assessment involves the developing an indicator system and identifying dependencies between the indicators. As many elements, which give a complete picture of the study object, influence on the living standards and quality of life of the population, they must be aggregated into groups of indicators which will strongly correlate with each other. In order to achieve our objective, the second stage of assessment involves the factor analysis, which is a set of sequential actions aimed at accumulating indicators that form a set, called factors. The factor analysis is used to minimize the number of independent values, detect correlation signs and latent (hidden) indicators, and allows to normalize the data, that is necessary for further research. The factor analysis put variables into a linear set of $F$-factors with minimum errors for the best representation of $X$ :

$$
X_{j}=\sum_{k=1}^{p} a_{j k} F_{K}+U_{j},
$$

where $F_{k}, k=1,2, \ldots$ are latent indicators, $\mathrm{p}$ are common factors, $a_{j k}$ values are called factor loadings, and $U_{j}, j=1,2, \ldots m$, are specific factors. 
The object for transformation in factor analysis is a variance-covariance matrix, consisting of $X$ data array. The result of these data compression is a reduced correlation matrix, i.e. the matrix is decreased in dimension, but not the data [Fulvio Castellacci 2018, J. Langford 2005]. The factor analysis conducted by the principal component method will result in the cumulative variance presented in Table 2 and in the rotated component matrix obtained by rotation method: Varimax rotation with Kaiser normalization shown in Table 3.

To implement the principal component analysis, it is necessary to normalize the indicators upon standard deviations. The $Z$ matrix based on the initial data is defined as follows:

$$
Z_{i j}=\frac{x_{i j}-x_{j}}{S_{j}},
$$

where $S_{j}$ is a standard deviation, $j=1,2, \ldots, m ; i=1,2, \ldots, n, x_{j}$ is an average value of the $j$-th feature to normalize the indicators is necessary for the further research.

Table 2. Explained variance

\begin{tabular}{|c|c|c|c|c|c|c|c|c|c|}
\hline \multirow{2}{*}{ 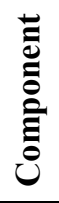 } & \multicolumn{3}{|c|}{ Initial eigenvalues } & \multicolumn{3}{|c|}{$\begin{array}{c}\text { Extraction sums } \\
\text { of squared loadings }\end{array}$} & \multicolumn{3}{|c|}{$\begin{array}{c}\text { Rotation sums } \\
\text { of squared loadings }\end{array}$} \\
\hline & Total & $\begin{array}{l}\text { Variance, } \\
\quad \%\end{array}$ & $\begin{array}{l}\text { Cumula- } \\
\text { tive, } \%\end{array}$ & Total & $\begin{array}{c}\text { Variance, } \\
\%\end{array}$ & $\begin{array}{c}\text { Cumula- } \\
\text { tive, } \%\end{array}$ & Total & $\underset{\%}{\text { Variance, }}$ & $\begin{array}{l}\text { Cumula- } \\
\text { tive, } \%\end{array}$ \\
\hline 1 & 4,241 & 41,375 & 47,124 & 4,241 & 41,375 & 47,124 & 3,658 & 40,642 & 40,642 \\
\hline 2 & 1,975 & 15,579 & 69,066 & 1,975 & 15,579 & 69,066 & 2,146 & 23,849 & 64,492 \\
\hline 3 & 1,559 & 12,357 & 86,393 & 1,559 & 12,357 & 86,393 & 1,971 & 21,901 & 86,393 \\
\hline 4 & 1,452 & 11,464 & 75,856 & 1,379 & 11,464 & 75,856 & 1,379 & 19,257 & 75,856 \\
\hline 5 & 0,852 & 9,464 & 55,856 & & & & & & \\
\hline 6 & , & , & , & , & , & , & 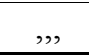 & , & , \\
\hline
\end{tabular}

The values exceeding one indicate that highly correlated indicators are classified upon four factors (indicators of the total variance F1 "Population income" - 41,375\%, F2 "Socio-economic indicators" - 15,579\%, F3 "Human potential" - 12,357\%, F4 "Digitalization" - 11,464\%).

The factor analysis results (the rotated $Z$ matrix generated by rotation method: Varimax rotation with Kaiser normalization) are shown in Table 2, which confirms that the indicators are classified upon four factors.

Table 3. Results of rotated matrix (generated by rotation method: Varimax rotation with Kaiser normalization)

\begin{tabular}{|c|c|c|c|c|}
\hline \multirow{2}{*}{ Coefficient name } & \multicolumn{4}{|c|}{ Factor } \\
\cline { 2 - 5 } & F1 & F2 & F3 & F4 \\
\hline Poverty level of the population (VAR00003) & $\mathbf{0 , 8 5 1}$ & 0,093 & 0,351 & 0,258 \\
\hline Unemployment rate (VAR00009) & 0,063 & $\mathbf{0 , 7 2 8}$ & 0,289 & 0,059 \\
\hline Level of education (VAR00012) & $-0,133$ & 0,041 & $\mathbf{0 , 9 0 9}$ & 0,123 \\
\hline Proportion of the population using the Internet & 0,231 & 0,089 & 0,153 & $\mathbf{0 , 6 5 8}$ \\
\hline$\ldots$ & $\ldots$ & $\ldots$ & $\ldots$ & \\
\hline
\end{tabular}


The Table shows that the poverty level of the population strongly correlates with the first factor, its factor loading is 0,851 , the unemployment rate tends to the second factor with the factor loading of 0,728 , the education level indicator has the factor loading of 0,909 , which clearly indicates a correlation with the third group of factors, as the loading on other groups is very low, the proportion of the population using the Internet will be referred to the fourth factor with the loading of 0,658 .

Another important feature of the factor analysis is that factor loadings indicate not only belonging to a particular group, but also reflect the impact of indicators as a whole on the system or factors. This is graphically represented in the following form (Fig. 2).
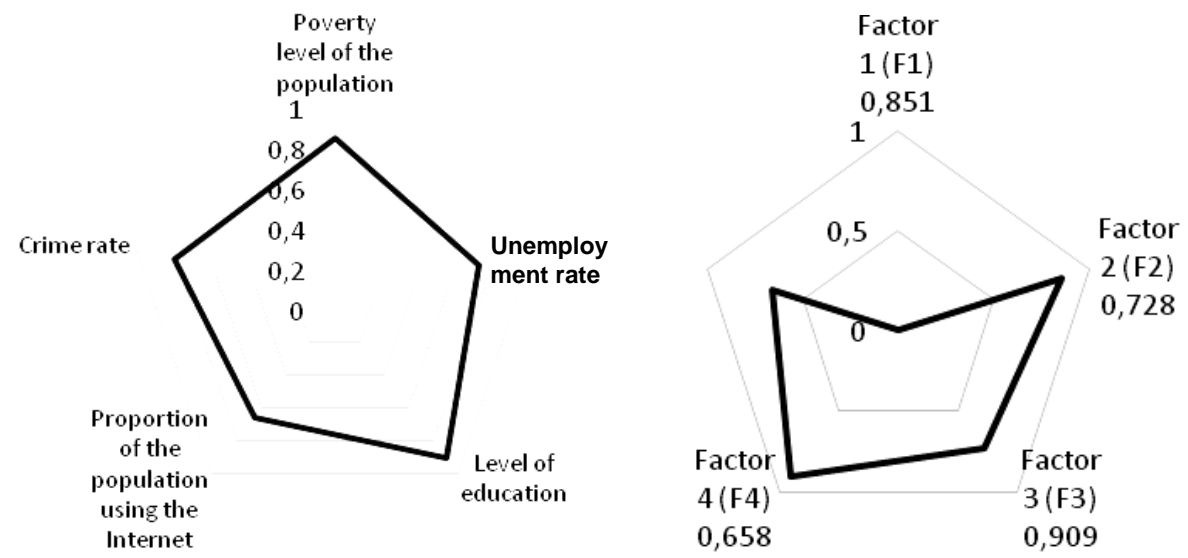

Fig. 2. Influence of variables or factors including factor loading

This advantage makes the factor analysis more attractive increasing the study objectivity, because there is no need to use an expert approach. This fact is also important when assessing the living standards and quality of life of the population.

The third stage of the algorithm involves the classification of municipalities according to the living standards of the population. Rostov Oblast is characterized by a high degree of differentiation in the development of its municipalities, therefore, the regional authorities need to solve a difficult task, i.e. to remove the existing differences not only in terms of socio-economic development, but also in the living standards of the population. For these purposes, first of all, they are to have a mathematical apparatus and verified system of indicators (the first and second stages of the rapid assessment), which make it possible to qualitatively classify the territory into groups close in the development indicators. In our opinion, the clustering methods, which are included in rapid assessment, namely, the iterative k-means method and seven hierarchical agglomerative methods deal well with this task.

The cluster analysis is a mechanism consisting of a set of methods and various similarity measures allowing to classify the variables $X_{1}, X_{2}, \ldots, X_{m}$. The main task of cluster analysis is to aggregate the groups of similar indicators, called clusters (clumps, groups, bundles). Past research experience allows us to conclude that the iterative k-means method gives the qualitative classification results. Its disadvantage is that a decision-maker needs to set a number of clusters on his own, and the hierarchical agglomerative methods do not require this [I.D. Mandel 1988, S.A. Ayvazyan 1989, T. Hastie, R. Tibshirani, J. Friedman 2009]. The cluster analysis results are visually presented either in scatter diagrams or in dendrograms, Fig. 3. 

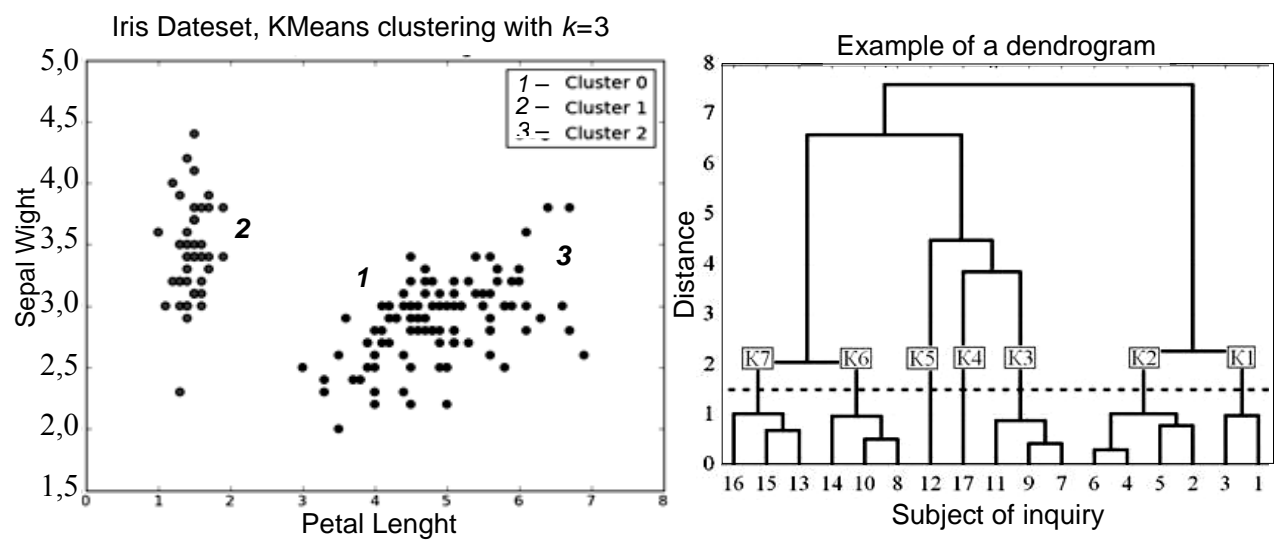

Fig. 3. Cluster analysis results presented in graphical form

Therefore, you may use all hierarchical agglomerative methods with all similarity measures to determine the number of clusters and their structural content, and then carry out the iterative $k$-means clustering, although the procedure is cumbersome, but with minimum errors.

As an example, the adjacency matrix with results of clustering of municipalities in Rostov Oblast is presented below. The calculations have shown that the most effective of the agglomerative metric classifiers are the "intragroup connections" and "Ward's method". The Table shows that classifying into five clusters is an optimal solution. The numbers indicate the administrative territorial units of Rostov Oblast [M.A. Lesnichaya, O.A. Kolchina, H.A. Kondzharyan 2019].

Table 4. Adjacency matrix of clustering results

\begin{tabular}{|c|c|c|c|c|c|}
\hline \multirow[b]{2}{*}{$\frac{n}{e_{0}^{0}}$} & \multicolumn{5}{|c|}{ Distance } \\
\hline & $\begin{array}{l}\text { Euclidean } \\
\text { distance }\end{array}$ & $\begin{array}{c}\text { Squared } \\
\text { Euclidean } \\
\text { distance }\end{array}$ & $\begin{array}{l}\text { Block distance } \\
\text { (Manhattan } \\
\text { distance) }\end{array}$ & $\begin{array}{l}\text { Minkowski } \\
\text { distance }\end{array}$ & $\cdots$ \\
\hline 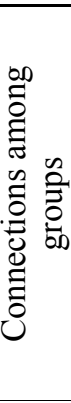 & $\begin{array}{c}\text { Contagion } \\
\text { effect }\end{array}$ & $\begin{array}{c}\text { Contagion } \\
\text { effect }\end{array}$ & $\begin{array}{l}\text { 1) } 10,48,22,35, \\
47,18,13,40,53, \\
29,30,7,23,31 \\
\text { 2) } 28,39,8,25,3, \\
2,44,46,54,38, \\
26,51,34,45,50, \\
52,55 \\
\text { 3) } 1,20 \\
\text { 4) } 15,27,49,41,14,42 \\
\text {,21,11, }\end{array}$ & $\begin{array}{c}\text { 1) } 10,48,22,35,47,18 \\
38,54 \\
24,30,7,29,13,40,53 \\
26,34,51,55,31 \\
\text { 2) } 8,39,25,28,3,45,50 \\
52,2,44,46 \\
\text { 3) } 1,20 \\
\text { 4) } 15,27,49,41,1\end{array}$ & $\cdots$ \\
\hline 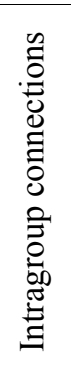 & $\begin{array}{c}\text { 1) } 10,48,22,41,35 \text {, } \\
47,18,38,54,51,55 \\
\text { 2) } 8,39,25,28,3,45 \\
, 50,52,2,44,46 \\
3) 17 \\
4) 1,2026,34,13,4 \\
0,53,7,29,30,24,3 \\
1\end{array}$ & $\begin{array}{c}1) 10,48,22,41,35,4 \\
7,18,38,54,31 \\
2) 13,40,53,7,29 \\
30,24 \\
3) 26,34,51,55,1,20 \\
4) 8,39,25,28,3,45, \\
50,52,2,44,46\end{array}$ & $\begin{array}{c}1) 10,48,22,41,35,47 \\
, 18,38,54,31,13,40 \\
53,7,29,30,24,26,34 \\
, 51,55 \\
2) 1,20,8,39,25,28,3 \\
45,50,52,2,44,46 \\
3) 15,27,49,12,14,42 \\
, \\
4) 5,23,36\end{array}$ & $\begin{array}{c}1) 10,48,22,35,47,18 \\
38,54,31 \\
2) 13,40,29,7,30,53,2 \\
4,26,34,51 \\
3) 16,43,9,19,6,4 \\
4) 14,42,21,32,15,49 \\
27,41,11,33,12,37\end{array}$ & $\cdots$ \\
\hline$\ldots$ & $\ldots$ & $\ldots$ & $\ldots$ & $\ldots$ & $\ldots$ \\
\hline
\end{tabular}


The iterative $k$-means clustering results are presented in Table 5 .

Table 5. K-means clustering results

\begin{tabular}{|c|c|c|c|c|c|}
\hline $\begin{array}{c}\text { Observation } \\
\text { number }\end{array}$ & Cluster & Distance & $\begin{array}{c}\text { Observation } \\
\text { number }\end{array}$ & Cluster & Distance \\
\hline 1 & 1 & 12,615 & 29 & 4 & 4,632 \\
\hline 2 & 2 & 6,305 & 30 & 5 & 4,995 \\
\hline 3 & 1 & 4,486 & 31 & 4 & 9,098 \\
\hline 4 & 3 & 8,575 & 32 & 3 & 5,365 \\
\hline 5 & 2 & 4,515 & 33 & 3 & 4,798 \\
\hline$\ldots$ & $\ldots$ & $\ldots$ & $\ldots$ & $\ldots$ & $\ldots$ \\
\hline
\end{tabular}

The $k$-means method is convenient and very easy to interpret the results. The Table shows that each observation is assigned its own cluster number depending on the distance, then an expert should structurally fill the groups. Observations present a study object. In our case, these are the municipalities of Rostov Oblast. The invaluable advantage of $k$-means method is the classification quality [Roberta Comunian and Lauren England 2019]. However, even such a voluminous classification procedure, including all agglomerative and iterative methods, does not exclude measurement errors, therefore, at the next stage, it is necessary to assess the resulting typology.

\section{CLASSIFICATION QUALITY ASSESSMENT}

It is advisable to use the discriminant analysis with Mahalanobis distance and Wilks lambda while assessing the obtained clustering results. This method has revealed the municipalities that were gathered into a different cluster by mistake. If we consider the discriminant constructing algorithm, it will represent the identification of a variable that causes the greatest differences among the observations [I.D. Mandel 1988, S.A. Ayvazyan 1989, T. Hastie, R. Tibshirani, J. Friedman 2009]. The results of discriminant analysis of the municipalities in Rostov Oblast are presented in Table. 6 .

Table 6. Discriminant analysis results

\begin{tabular}{|c|c|c|c|c|c|c|}
\hline \multirow{2}{*}{$\begin{array}{c}\text { Case } \\
\text { number }\end{array}$} & Factor \\
group & $\begin{array}{c}\text { Predicted } \\
\text { group }\end{array}$ & \multicolumn{5}{|c|}{ Senior group } \\
\hline & & & $p$ & $d f$ & & $\begin{array}{c}\text { Squared Mahalanobis } \\
\text { distance } \\
\text { to the centroid }\end{array}$ \\
\hline 1 & 1 & 1 & 0,873 & 3 & 0,825 & 1,378 \\
\hline 2 & 1 & $1 * *$ & 0,628 & 3 & 0,753 & 4,521 \\
\hline 3 & 2 & 2 & 0,542 & 3 & 0,513 & 1,617 \\
\hline 4 & 3 & 2 & 0,758 & 3 & 0,423 & 2,251 \\
\hline$\ldots$ & $\ldots$ & $\ldots$ & $\ldots$ & $\ldots$ & $\ldots$ & $\ldots$ \\
\hline
\end{tabular}

In the sample for each group of observations, the point position is determined in multidimensional space. This point is an average value for all variables, 
i.e. centroid groups. Then, for each observation, the squared Mahalanobis distance from a group centroid is calculated. The closer the observation is to the set, the more minimum the Mahalanobis distance is to it (the observation is classified correctly). The "Predicted group" column (Table 6) has a mark "**”, indicating an incorrectly assigned variable to the set. The results of discriminant analysis can also be presented in a classification matrix containing the number of variables located on the matrix diagonal, i.e. correctly classified and those that do not belong to their classes. When conducting the research, assessing the quality of the resulting classification is necessary, because the observations represent the specific municipalities, groups of people, who, due to measurement errors, may receive less financial assistance, therefore any errors in this area are critical and unacceptable. The clustering results on the living standards of the population of Rostov Oblast with the use of discriminant analysis are presented in Table. 7.

T a b l e 7. Results of clustering of municipalities in Rostov Oblast

\begin{tabular}{|c|c|}
\hline Clusters & Municipalities of Rostov Oblast \\
\hline Cluster 1 & Cities: Rostov-on-Don (53), Volgodonsk (46), Taganrog (54), Gukovo (47), \\
Zverevo (49)
\end{tabular}

The municipalities of Rostov Oblast were accumulated in 5 clusters with different living standards of the population from a higher (cluster I) to a lower one (cluster V), that makes it possible for the authorities to distribute financial resources more efficiently, support various categories of the population and develop programs for improving the living standards, taking into account the specifics of the territories included in different clusters.

\section{RANKING OF TERRITORIAL ENTITIES}

The final stage of rapid assessment is to determine a place of the studied territory in terms of the living standards of the population in the overall ranking of administrative-territorial entities using the index method of ranking statistical observations [M.A. Lyamina 2008]. This algorithm is presented in the flowchart (a program in the VBA language is developed) in Fig. 4. 

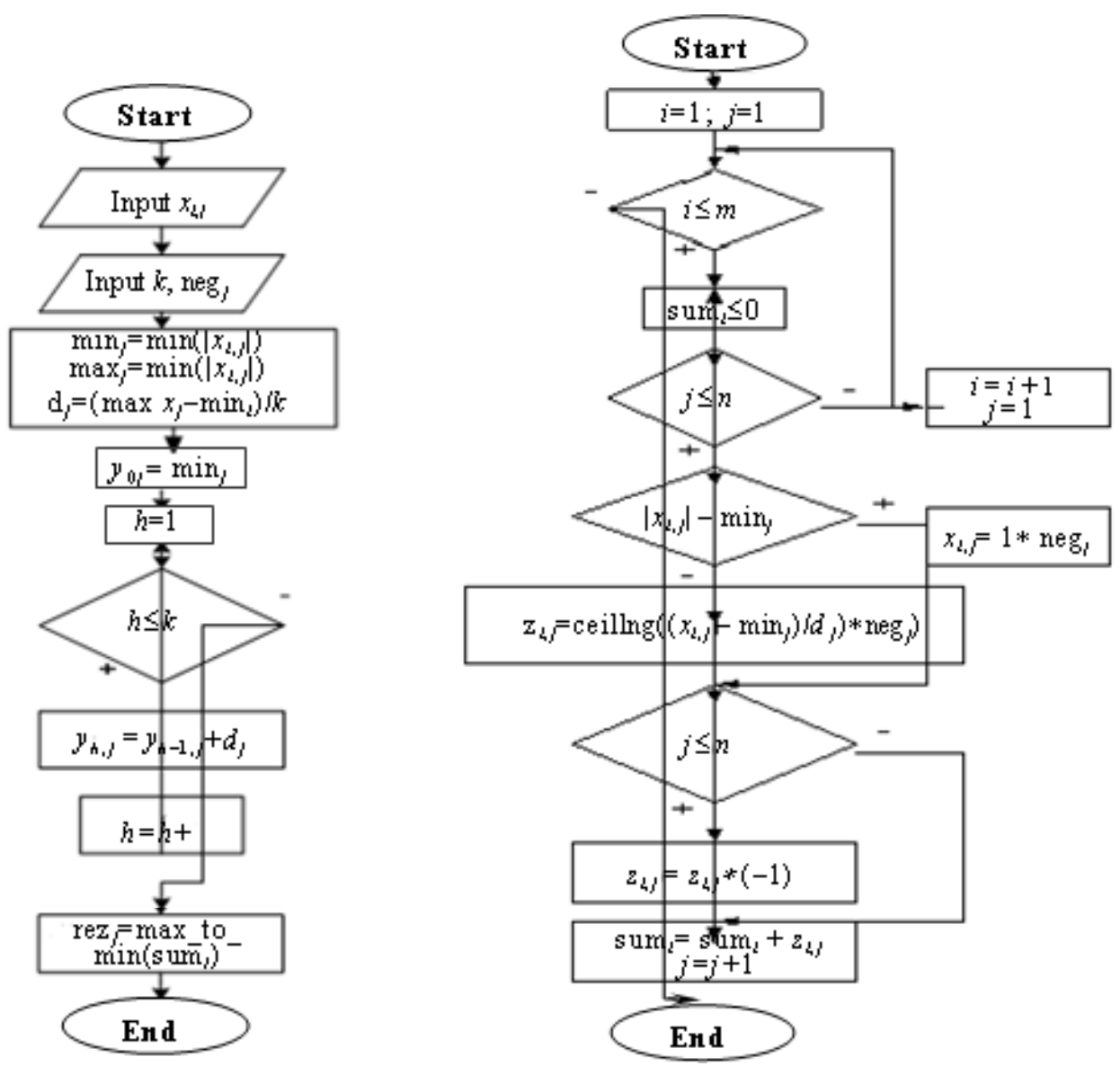

Fig. 4. Flowcharts of the index method algorithm for ranking statistical observations

The method essence is to form an equal range scale of real values of the investigated statistical observations from a minimum indicator to a maximum one. Each range is assigned a rank which corresponds to the interval number. By means of a graduation scale, the ranks are summed up, forming an integral indicator. This, on the one hand, will allow to include the maximum set of variables in the assessment system, and, on the other hand, based on the author's indicator system, to make a scientifically grounded rating of administrativeterritorial entities.

Ranking is an important stage of monitoring, as it helps evaluate the effective activities of the authorities both in the field of improving the living standards of the population and in other areas, using a rather simple mechanism.

\section{DISCUSSION}

According to the UN and other public organizations, Russia lags significantly behind the leading countries of the world in various integral indicators of quality of life. Therefore, the problems of studying the characteristics of the living standards and quality of life of the population are significant in modern economic theory, and it becomes especially urgent to develop an effective tool for their comprehensive assessment.

A theoretical study of the quality of life was begun in the $1860 \mathrm{~s}$ in economically developed countries. A significant contribution to defining the 
"quality of life" category as a multifaceted concept of modern social progress was made by famous foreign scientists, such as A. Toynbee, D. Bell, J. Galbraith, R. Aron, H. Kahn, A. Viner, H. Marcuse, and E. Fromm.

The economic aspects of the living standards and quality of life of the population are considered in the works of M.V. Borschevsky, L.A. Velikhov, M.V. Glazyrin, B.S. Zhikharevich, I.A. Ilyin, A.E. Koguta, V.N. Leksin, N.V. Lvov, V.Ya. Lyubovny, V.F. Mayer, V.E. Rokhchin, V.M. Rutgeiser, A.E. Surinov and others. Social problems are studied in the works of N.A. Aitov, E.G. Ayayimitsy, A.V. Baranov, A.V. Dmitriev, E.N. Zaborova, M.N. Mezhevich, A.E. Polovinkin, I.I. Sigov and others.

In recent years the problems of economic and statistical assessment of the living standards and quality of life have been actively discussed by the domestic economists, such as S.A. Ayvazyan, A.M. Dubrov, V.M. Zherebin, V.S. Knyazevsky, V.S. Mkhitaryan, L.I. Nivorozhkina, V.D. Raitsin, N.M. Rimashevskaya, A.N. Romanov, I.I. Eliseeva, L.I. Troshin, G.N. Khubaev and others.

The issues of overcoming unevenness and stabilizing significant imbalances in the socio-economic development levels of the Russian regions and the problems of forming a single economic space are considered in the works of A.G. Granberg, E.B. Kibalov, V.I. Klistorin, V.V. Kuleshov, A.M. Lavrov, B.L. Lavrovsky, V.N. Leksin, V.Yu. Malov, V.D. Marshak, V.E. Seliverstov, V.I. Suslov, S.A. Suspitsyn, V.A. Shabashev and others.

Despite the high relevance of intraregional differentiation, Russia still neglects its removal. The authors study certain aspects of this phenomenon: the issues of socio-economic development of municipalities (E.G. Animitsa, R.V. Babun, G.Yu. Vetrov, A.G. Voronin, A.P. Gaponenko, B.S. Zhikharevich, V.V. Ivanov, E.A. Kartaeva, Yu.S. Kolesnikov, V.A. Lapin, V.N. Leksin, Z.Z. Mullagaleeva, P.A. Orekhovsky, A.N. Shvetsov and others) and local government (A.A. Vasiliev, A.N. Shirokov, S.N. Yurkova).

Much attention is paid to the study of sustainable development problems in the works of such domestic authors as I.Ya. Blekhtsin, S.N. Bobylev and V.I. Vernadsky, I.F. Gazizullin, A.A. Golub, V.I. Danilov-Danilyan, V.A. Koptyug, N.N. Moiseev, O.S. Pchelintsev, A.D. Ursul and others. Among the foreign researchers of these problems are D. Bell, D. Meadows and J. Forrester.

\section{MATERIALS AND METHODS}

The statistical data published in monthly reports of the Rostov Regional State Statistics Committee, statistical yearbooks and reference books have formed the information and empirical base of the study.

The theoretical basis of the study consists of the fundamental concepts of the management theory of socio-economic systems, works of domestic and foreign scientists in the field of studying the living standards and quality of life of the population, uneven spatial economic development of the regions, digitalization of the regional and municipal economy, organization and management in the public and state sectors, service economy, institutional economics and the legislative regulatory documents of the government authorities and local government bodies of the Russian Federation.

The study methodology is based on:

- the system analysis methods and mathematical modelling used for designing a concept and modelling the sustainable development of the region in the conditions of inter-municipal differentiation; 
- the factor analysis methods used for determining the dominant indicators of development of the regions and municipalities;

- the cluster analysis methods used for solving the problems of cluster convergence analysis of socio-economic development levels of the regions and differentiation of municipalities;

- the economic dynamics forecasting methods used for predicting the dynamics of regional development;

- the management theory methods used for creating management models for integrated sustainable development of municipalities;

- the discriminant analysis method used for assessing the quality of territory classification and identifying the factors contributed the most in intergroup differences (focusing on the values of Wilks Lambda and squared Mahalanobis distance)[ W.R. Klecka 1989].

In their study the authors have used domestic and foreign experience of economic and mathematical tools for analyzing and predicting the living standards and quality of life of the population. The study was carried out using general software (Microsoft Excel) and special software (STATISTICA, SPSS).

\section{CONCLUSIONS}

The proposed rapid assessment algorithm will form the basis for an analytical program designed to support the management decisions made by the authorities to improve the living standards and quality of life in order to remove inter-municipal differences.

The management tasks that can be solved by the proposed assessment method are as follows:

- to simulate various scenarios for the situation development, which is an important criterion in the dynamically changing conditions of modern economy;

- by means of ranking, to assess the effective actions of the authorities;

- to implement the experience of more successful administrative-territorial entities in their own territory;

- to reveal the development differences of the territories, identify the indicators that have the greatest impact on stratification of the population in terms of the living standards, and to reveal the systemic problems decreasing the living standards of the specific territories;

- to allow the authorities rationally to distribute financial resources aimed at supporting the specific territories in order to improve the quality, speed and effectiveness of the proposed development programs.

The developed system for rapid assessment of the living standards and quality of life of the population is a basic screening tool for supporting management decisions. Due to a diverse set of methods for processing statistical data, the methodology demonstrates high quality and speed of calculations, the versatility of assessment allows users with different skill levels to conduct researches, changing a system of variables and object to meet their requirements, and rationally to allocate financial resources aimed at improving the living standards and quality of life population. The proposed methodology will improve the existing service in Rostov Oblast "Building a regional poverty profile", which is currently aimed only at providing assistance to poor citizens [https://smarteka.com/practices/vyavlenie-maloimusih-grazdan-s-maksimalnojdekompoziciej-harakteristik-maloimusih.]. 
The proposed algorithm efficiency and effectiveness was proved by the state statistics data of the municipalities of Rostov Oblast.

Author contributions: Writing-review \& editing, M.L., O.K. and E.P. All authors have read and agreed to the published version of the manuscript.

Funding: The study was financially supported by the Russian Foundation for Basic Research (RFBR), the project "Developing a concept of improving the living standards and quality of life of the population in the region in the conditions of inter-municipal differentiation, taking into account the economy digitalization" No. 20-010-00815 A.

Conflicts of interest: The authors declare no conflict of interest.

\section{REFERENCES}

1. W.R. Klecka, Factor, discriminant and cluster analysis, (in Russian). Moscow: Finance and Statistics, 1989, $215 \mathrm{p}$.

2. I.D. Mandel, Cluster analysis, (in Russian). Moscow: Finance and Statistics, 1988, 176 p.

3. S.A. Ayvazyan, V.M. Buchstaber, I.S. Enyukov, and L.D. Meshalkin, Applied statistics: classification and dimensionality reduction, (in Russian). Moscow: Finance and Statistics, 1989.

4. T. Hastie, R. Tibshirani, and J. Friedman, The Elements of Statistical Learning, 2nd edition. Springer, 2009, $533 \mathrm{p}$.

5. J. Langford, Tutorial on Practical Prediction Theory for Classification, 2005, $28 \mathrm{p}$.

6. M. Zhambyu, Hierarchical cluster analysis and correspondence, (in Russian). Moscow: Finance and Statistics, 1988, 345 p.

7. N.V. Zubarevich, "Russian regions in January-July 2019: Mix of growth, stagnation and slump", Russian Economic Development, vol. 26, no. 10.

8. Roberta Comunian and Lauren England, "Creative Clusters and the Evolution of Knowledge and Skills: From Industrial to Creative Glassmaking", Geoforum, 99, pp. 238-247, 2019.

9. M.A. Lesnichaya, O.A. Kolchina, and H.A. Kondzharyan, "Elaboration of a conceptual scheme of municipal units classification according to the level of budgetary provision on the base of cluster analysis (2019)", Proceedings of the 2019 IEEE Conference of Russian Young Researchers in Electrical and Electronic Engineering, ElConRus 2019, article no. 8657216, pp. 1415-1420.

10. Marcelo Cano-Kollmann, John Cantwell, Thomas J. Hannigan, Ram Mudambi, and Jaeyong Song, "Knowledge Connectivity: An Agenda for Innovation Research in International Business", Journal of International Business Studies, 47, pp. 255-262, 2016.

11. Fulvio Castellacci, "Co-Evolutionary Growth: A System Dynamics Model", Economic Modelling, 70, pp. 272-287, 2018.

12. M.A. Lyamina, "An approach to design of intelligent system rapid assessment for the mortgage climate of the constituent entities of the Russian Federation" (in Russian), Technical science, no. 10 (87), pp. 23-28, 2008.

13. Smarteka.com. Available: https://smarteka.com/practices/vyavlenie-maloimusihgrazdan-s-maksimal-nojdekompoziciej-harakteristik-maloimusih.

14. The Economist Intelligence Unit's quality-of-life index. Available: https://www. eiu.com $/ \mathrm{n} /($ accessed on 26.06.20).

15. United Nations Development Programme, Human Development Reports 2019. Available: http://hdr.undp.org/en/content/2019-human-development-index-ranking (accessed on 26.06.20).

Received 18.04.2021

\section{INFORMATION ON THE ARTICLE}

Marina A. Lesnichaya, ORCID: 0000-0001-8978-5104, Institute of Management in Economic, Environmental and Social Systems, Southern Federal University, Russia, e-mail: grezinam@yandex.ru 
Oksana A. Kolchina, ORCID: 0000-0003-4161-9769, Institute of Management in Economic, Environmental and Social Systems, Southern Federal University, Russia, e-mail: kolchinaoksana@gmail.com

Evgenii V. Pahomov, ORCID: 0000-0002-3898-1444, Institute of Management in Economic, Environmental and Social Systems, Southern Federal University, Russia, e-mail: evpahomov@sfedu.ru

РОЗРОБЛЕННЯ АЛГОРИТМУ МЕТОДИКИ ЕКСПРЕС-ОЦІНКИ РІВНЯ ТА ЯКОСТІ ЖИТТЯ НАСЕЛЕННЯ РЕГІОНУ / М.О. Ліснича, О.О. КоЛчИна, Е.В. Пахомов

Анотація. Запропоновано методику експрес-оцінки, яка дозволить аналітикам проводити якісний моніторинг рівня життя населення, використовуючи широкий набір методів оброблення статистики (факторний аналіз, кластерний аналіз, дискримінантний аналіз, метод об'єднання різновимірних показників), що відрізняється високою швидкістю математичних обчислень, доступністю користувачам з різним рівнем кваліфікації, універсальністю застосування для різних об'єктів дослідження. Метод експрес-оцінки призначено для скринінгу рівня життя населення і якості діяльності органів влади територіальних утворень $з$ урахуванням набору різних показників. Запропоновано авторську систему показників оцінювання рівня та якості життя населення. В алгоритмі методики описано блок-схеми індексного методу об'єднання різновимірних статистичних спостережень, що дозволяють автоматизувати процес ранжування територій. Як об’єкт дослідження обрано 12 міських і 43 муніципальних округів району Ростовської області. Застосування описаної методики дасть змогу: вилучити суб'єктивний фактор під час проведення моніторингу; раціонально розподіляти фінансові ресурси, які щорічно виділяються органами влади на підтримання програм соціально-економічного розвитку території; підвищити економічну ефективність i пришвидшити впровадження інноваційних проєктів, що безпосередньо впливають на рівень і якість життя населення.

Ключові слова: рівень життя населення, тренди динаміки, редукція змінних, кластеризація, оцінювання якості класифікації, ранжування.

\title{
РАЗРАБОТКА АЛГОРИТМА МЕТОДИКИ ЭКСПРЕСС-ОЦЕНКИ УРОВНЯ И КАЧЕСТВА ЖИЗНИ НАСЕЛЕНИЯ РЕГИОНА / М.А. Лесничая, О.А. КоЛчина, Е.В. Пахомов
}

\begin{abstract}
Аннотация. Предложена методика экспресс-оценки, позволяющая аналитикам проводить качественный мониторинг уровня жизни населения, используя широкий набор методов обработки статистики (факторный анализ, кластерный анализ, дискриминантный анализ, метод объединения разномерных показателей), отличающаяся высокой скоростью математических вычислений, доступностью пользователям с разным уровнем квалификации, универсальностью применения для различных объектов исследования. Метод экспресс-оценки предназначен для скрининга уровня жизни населения и качества деятельности органов власти территориальных образований, учитывающий различный набор показателей. Предложена авторская система показателей оценки уровня и качества жизни населения. В алгоритме методики описаны блок-схемы индексного метода объединения разномерных статистических наблюдений, позволяющие автоматизировать процесс ранжирования территорий. В качестве объекта исследования были выбраны 12 городских округов и 43 муниципальных района Ростовской области. Применение описанной методики позволит: исключить субъективный фактор при проведении мониторинга; рационально распределять финансовые ресурсы, ежегодно выделяемые органами власти на поддержку программ социально-экономического развития территории; повысить экономическую эффективность и скорость внедрения инновационных проектов, которые оказывают непосредственное влияние на уровень и качество жизни населения.
\end{abstract}

Ключевые слова: уровень жизни населения, тренды динамики, редукция переменных, кластеризация, оценка качества классификации, ранжирование. 